\title{
Taxonomy of Ixinandria Isbrücker \& Nijssen (Loricariidae: Loricariinae) based on morphological and molecular data
}

\author{
Mónica S. Rodriguez ${ }^{1}$, Christian A. Cramer ${ }^{2}$, Sandro L. Bonatto ${ }^{2}$ and Roberto E. Reis ${ }^{2}$
}

The genus Ixinandria was described in 1979 to include I. steinbachi from the upper río Juramento in northern Argentina and I. montebelloi from the upper río Bermejo in southern Bolivia. We used a multivariate morphometric analysis (Principal Components Analysis) and a molecular comparison of the Cytochrome Oxidase I gene to investigate variation among distinct populations from the known distribution range of both species. We conclude that the populations are not significantly distinct and do not deserve separate species recognition, and we place I. montebelloi in the synonymy of I. steinbachi.

O gênero Ixinandria foi descrito em 1979 para incluir I. steinbachi do alto rio Juramento no norte da Argentina e I. montebelloi do alto rio Bermejo no sul da Bolívia. Utilizamos análise morfométrica multivarida (Análise de Componentes Principais) e uma comparação molecular do gene Citocromo Oxidase I para investigar a variação entre populações distintas da área de distribuição de ambas as espécies. Concluímos que as populações não são significativamente distintas e não merecem reconhecimento como espécies separadas, e colocamos Ixinandria montebelloi na sinonímia de I. steinbachi.

Key words: Neotropical, Synonymy, río Juramento; río Bermejo; río Pilcomayo.

\section{Introduction}

Ixinandria Isbrücker \& Nijssen, 1979 was described to accommodate two species, Loricaria steinbachi Regan, 1906, the type species, and Canthopomus montebelloi Fowler, 1940. Ixinandria was considered by the authors to be very close to Rineloricaria Bleeker, 1862, and diagnosed on the basis of the absence of abdominal plates, the degree of development of odontodes, and the shape of the head in sexually mature males (Isbrücker, 1979). Isbrücker (1979) placed Ixinandria in the subtribe Rineloricariina, which also included Spatuloricaria Schultz, 1944, Dasyloricaria Isbrücker \& Nijssen, 1979, and Rineloricaria. The validity of Ixinandria or its relationships with other loricariines were never further investigated.

Loricaria steinbachi was placed in the subgenus Rhineloricaria by Eigenman (1911), a few years after its original description, and remained as Rineloricaria until it was moved to Ixinandria by Isbrücker (1979). On the other hand, Canthopomus montebelloi remained mostly unnoticed until Isbrücker's (1979) new combination by its inclusion in the genus Ixinandria.

Loricaria steinbachi was described from the río Juramento basin, a tributary to the río Salado drainage, near Cachi, Salta, Argentina, at an elevation of 2,500 meters above sea level, based on three specimens. Isbrücker (1979) later designated the larg- est of those three syntypes as the lectotype. Canthopomus montebelloi was described from tributaries of the upper río Bermejo at the Monte Bello Farm in Tarija, southern Bolivia, based on the holotype only, also from high elevation.

The validity of those species was later questioned by Isbrücker (1981a), who suggested that they might represent a single species. In this paper, we revised the two species and placed Ixinandria montebelloi in the synonymy of I. steinbachi, based on both morphological and molecular evidence.

\section{Material and Methods}

The morphometric variables were measured with a digital caliper ( $0.1 \mathrm{~mm}$ precision). The measurements and counts follow Isbrücker \& Nijssen (1978), except the following: Counts of lateral plates with coalesced keels and the measurement of cleithral width were made according to Reis \& Pereira (2000); and eye diameter was measured according to Isbrücker (1973). Names and counts of lateral plate rows and rostral plates follow Schaefer (1997). Osteological observations were made on specimens cleared and stained (c\&s) prepared according to the method of Taylor \& Van Dyke (1985).

We used Principal Components Analysis (PCA) to investigate morphometric variation among four distinct populations of Ixinandria, encompassing the area of distribution of both I. steinbachi and I. montebelloi. A total of 30 morphometric

\footnotetext{
${ }^{1}$ Laboratório de Ictiologia de Ribeirão Preto (LIRP), Departamento de Biologia, FFCLRP, Universidade de São Paulo, Avenida Bandeirantes 3900, 14040-901 Ribeirão Preto, SP, Brazil. rodriguez.monica@yahoo.com.ar

${ }^{2}$ Faculdade de Biociências, Pontifícia Universidade Católica do Rio Grande do Sul, Av. Ipiranga 6681, 90619-900 Porto Alegre, RS, Brazil.
} 
variables (Table 1) was taken from 73 specimens representing comparable size ranges: a population from the río Juramento basin, upper río Salado drainage, type-locality of Ixinandria steinbachi $(\mathrm{n}=16,58.2-91.6 \mathrm{~mm} \mathrm{SL})$, a population from the upper río Bermejo drainage in northern Argentina $(\mathrm{n}=18,56.4-$ $112.8 \mathrm{~mm} \mathrm{SL}$ ), a population from the upper río Bermejo in southern Bolivia, type-locality of Ixinandria montebelloi $(\mathrm{n}=37,68.9-100.3 \mathrm{~mm} \mathrm{SL})$, and two specimens from the upper río Pilcomayo in Bolivia ( $\mathrm{n}=2,72.7$ and $76.6 \mathrm{~mm} \mathrm{SL}$ ). Principal components analysis was performed on the co-variance matrix of the $30 \log$-transformed measurements. Factor scores were plotted for the PC II, III and IV, interpreted to represent size-free shape (Bookstein, 1989).

In the lists of material museum abbreviations and catalog number are presented first, followed by the number of specimens in that lot, size range, number and size range of measured specimens in parentheses, and locality. Institutional abbreviations are according to Reis et al. (2003), with the addition of Museo de Ciencias Naturales, Universidad Nacional de Salta, Salta (MCNI), and Universidad Mayor de San Simón, Cochabamba (UMSS).

Scanning electronic micrographs were made at the Facultad de Ciencias Naturales y Museo (Universidad Nacional de La Plata) and Centro de Microscopia e Microanálises (Pontificia Universidade Católica do Rio Grande do Sul).

For molecular analyses we used tissue samples from six localities as follows: 12 specimens from two localities in the río Arenales, tributary to the río Juramento near Salta, Argentina; 10 specimens from the río La Caldera and arroyo Lesser, tributaries to the río Bermejo near Salta, Argentina; and 11 specimens from the río Gaudalquivir and río Camacho, tributaries to the río Bermejo near Tarija, Bolivia. In addition, we used sequences from two outgroup species taken from GenBank (Apistoloricaria ommation EU359403 and Rineloricaria sp. EU359461).

From total genomic DNA extracted from ethanol-preserved tissue using the QIAmp tissue kit (Qiagen, Hilden, Germany), we amplified and sequenced a 709 basepair fragment of the mitochondrial Cytochrome Oxidase I gene, using the primers LCO1490 and HCO2198 (Hebert et al. 2003). Each PCR was carried out in $20 \mu \mathrm{l}$ reactions with the following concentrations: 1x Invitrogen PCR buffer (Invitrogen, São Paulo), 1.5$2.5 \mathrm{mM} \mathrm{MgCl}_{2}, 0.2 \%$ Triton, $200 \mu \mathrm{M}$ of each dNTP, $0.025 \mathrm{U} / \mu \mathrm{l}$ Taq polymerase (Invitrogen, São Paulo), $0.2 \mu \mathrm{M}$ of each primer and up to $2 \mu 1$ of DNA solution.

We used a non-standard protocol for this primer pair with an initial denaturation step of $1 \mathrm{~min}$ at $96^{\circ} \mathrm{C}$ followed by 40 cycles of $94^{\circ} \mathrm{C}$ for $30 \mathrm{~s}$, annealing at $50^{\circ} \mathrm{C}$ for $20 \mathrm{~s}, 48^{\circ} \mathrm{C}$ for $5 \mathrm{~s}$, $46^{\circ} \mathrm{C}$ for $5 \mathrm{~s}, 44^{\circ} \mathrm{C}$ for $5 \mathrm{~s}, 42^{\circ} \mathrm{C}$ for $5 \mathrm{~s}, 40^{\circ} \mathrm{C}$ for $20 \mathrm{~s}$ and extension at $72^{\circ} \mathrm{C}$ for $1 \mathrm{~min}$. This was followed by a final $3 \mathrm{~min}$ at $72^{\circ} \mathrm{C}$ extension step. Amplification success was evaluated on GelRed $^{\text {TM }}$ (BioTium, São Paulo) or ethidium bromide-stained agarose gels (Sambrook et al. 1989). PCR products were purified using PEG8000, ExoSAP-IT ${ }^{\circledR}$ (USB) or the ilustra ${ }^{\mathrm{TM}}$ GFX PCR and Gel Band Purification Kit (GE Healthcare, Buckinghamshire, UK). Sequencing was done using the
DYEnamic ${ }^{\mathrm{TM}}$ ET dye terminator kit (GE Healthcare, São Paulo) read in a MegaBace1000 sequencer. Sequences were edited and combined using BioEdit 7.0.1 (Hall 1999).

Sequences were aligned using Clustal X 1.83 (Thompson et al., 1997) with the standard settings. PAUP*4.0b10 (Swofford, 2001) was used to analyze the data with respect to the parsimony and the maximum likelihood criteria. For the maximum parsimony (MP) analysis we used the tree-bisection-reconnection (TBR) search algorithm with 1000 replicates in which taxa were added randomly to the starting tree. All characters were treated as unordered and transformations were assigned equal weight. Nodal support was evaluated with 1000 nonparametric bootstrap pseudoreplicates (Felsenstein, 1985) using the TBR search algorithm on a starting tree to which taxa were added randomly. Multiple optimal topologies were summarized through consensus methods. The maximum likelihood (ML) analysis was done using the TVM $+\mathrm{G}$ model found with Modeltest 3.7 (Posada \& Crandall, 1998). Nodal support was evaluated with 1000 nonparametric bootstrap pseudoreplicates.

A haplotypic network was calculated using Network 4.5.0.0 (Bandelt et al., 1999). An Analysis of Molecular Variance (AMOVA) and a fixation index $\left(\mathrm{F}_{\mathrm{ST}}\right)$ analysis were calculated using Arlequin 3.11 (Excoffier et al., 2005). Mega 3.1 (Kumar et al., 2004) was used to calculate sequence divergences using Kimura-2-parameter (K2P) distance.

\section{Results}

Multivariate analysis. The resulting first principal component included a large proportion of the total variance (78.6\%) and all variable loadings were positive and varied little in magnitude, suggesting that it represents a general size factor. Plots of factor scores of principal component II vs. III grouped specimens into four broadly overlapping clusters (Fig. 1). PC II and III included 4.5 and $4.0 \%$ of the total variance, respectively. Measurements with heavier loadings on PC II are analfin spine length (0.395), body width at dorsal-fin origin ($0.416)$ and body depth at dorsal-fin origin (-0.434); on PC III are dorsalmost principal caudal-fin ray (-0.407), ventralmost principal caudal-fin ray (-0.386) and eye diameter (0.395). Plots of factor scores of PC II vs. IV also grouped specimens into four overlapping clusters (Fig. 1). PC IV included $2.5 \%$ of the total variance and heavier loadings on PC IV were on thoracic length (0.247) and internareal width (-0.487).

Molecular analysis. We obtained an alignment with 35 sequences with 709 contiguous nucleotides. The character matrix contained 42 parsimony-informative characters. The MP analysis resulted in 26 equally parsimonious trees with a length of 151 steps. Their summarized strict consensus tree is shown in Fig. 2. The single best tree found in the ML analysis has a - $\ln \mathrm{L}$ score of -1643.94356 and is shown in Fig. 3.

Based on the geographic distances we considered our samples to be from three populations: Juramento (río Arenales), Bermejo 1 (río Caldera and arroyo Lesser) and Bermejo 2 (río 
Gaudalquivir and río Camacho). The Network showed the population Bermejo 2 separated from Juramento and Bermejo 1 which, in turn, could not be separated (Fig. 4).

The AMOVA showed that the sequences from the samples from Tarija are significantly different $(\mathrm{p}=0.0000)$ from the other samples. The samples from Salta did not show any significant difference $(\mathrm{p}=0.39640 \pm 0.0243)$. Our sequences showed an avereage $\mathrm{K} 2 \mathrm{P}$ distance of $1.1 \%$.

Ixinandria Isbrücker \& Nijssen, 1979

Ixinandria Isbrücker \& Nijssen, in Isbrücker, 1979: 87 and 91, figs. 1-4. Type species: Loricaria steinbachi Regan, 1906, by original designation. Gender: feminine.
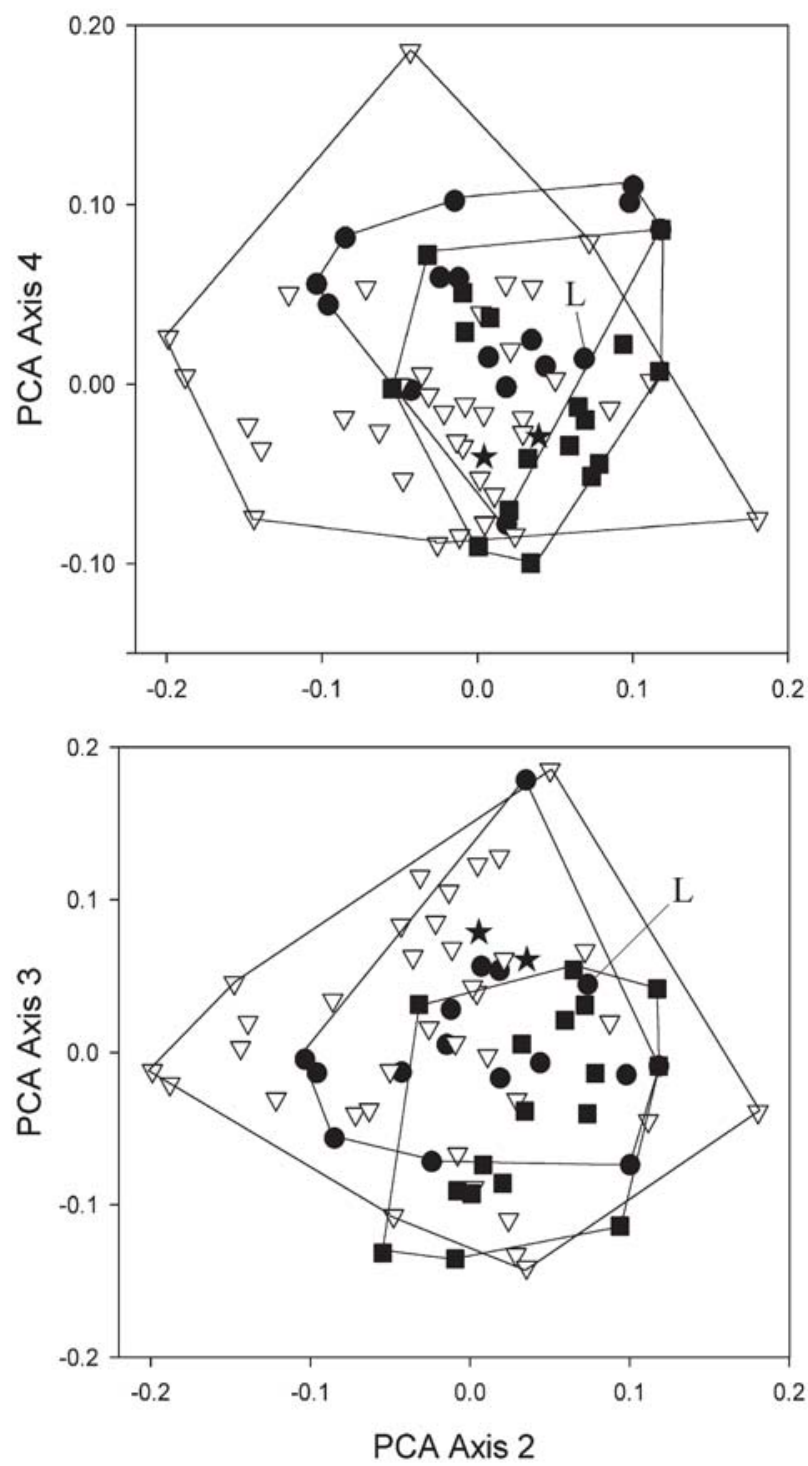

Fig. 1. Plots of factor scores of principal component analysis of four populations of Ixinandria steinbachi. Dot, río Juramento basin; Square, southern upper río Bermejo basin; triangle, northern upper río Bermejo basin; and Star, río Pilcomayo. $\mathrm{L}=$ lectotype.
Diagnosis. Among loricariines Ixinandria is most similar to Rineloricaria and can be distinguished from most genera by the total lack of abdominal plates, including the preanal plate. Hartiella and a few species of Harttia also have the abdomen completely devoid of plates, and can be distinguished from Ixinandria by having 12 branched caudal-fin rays (vs. 10 in Ixinandria) and by the absence of postorbital notch, which is present in Ixinandria. Species of Crossoloricaria,

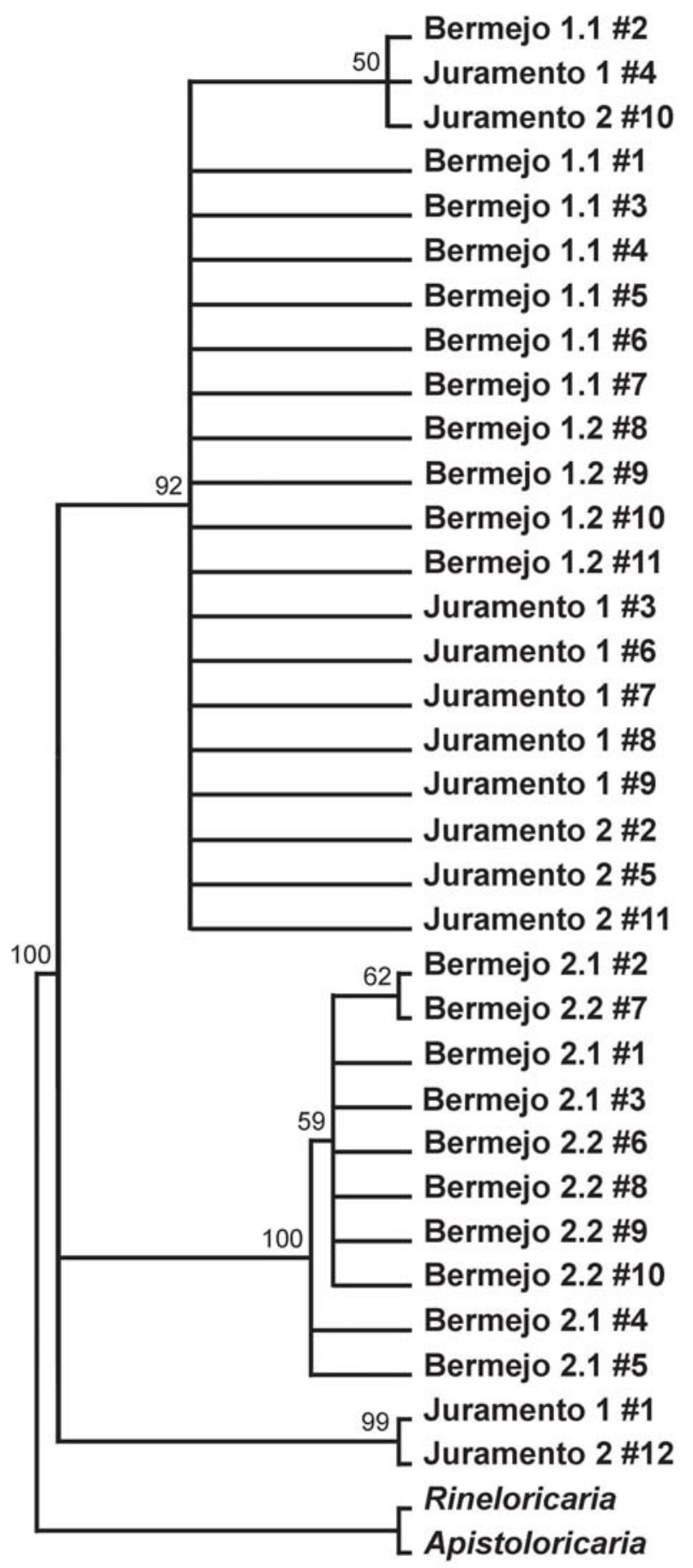

Fig. 2. Strict consensus of the 26 best trees from the maximum parsimony analysis. Tree length: 151 . Numbers above branches are values from 1000 bootstrap replications. 


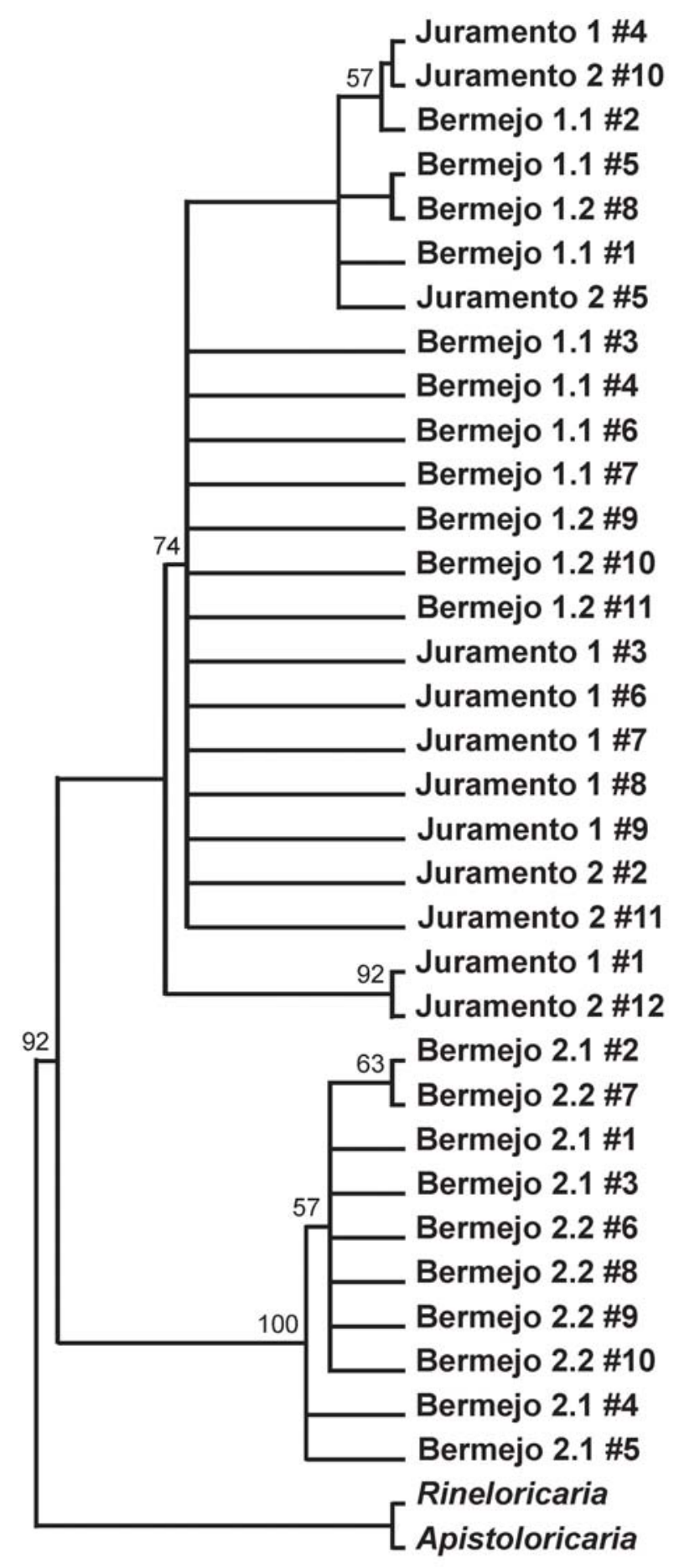

Fig. 3. Best tree from maximum likelihood analysis. - In $\mathrm{L}=1643.94356$. Numbers above branches are values from 1000 bootstrap replications.

Spatuloricaria, and Loricaria sometimes lack a preanal plate, but small abdominal plates are present. Some species of Rineloricaria have a naked abdomen, but a preanal plate is always present, except in $R$. setepovos. This species, however, has a caudal-fin filament and 3-4 premaxillary teeth. Ixinandria can also be distinguished from other loricariines by the shape and number of premaxillary teeth. Ixinandria

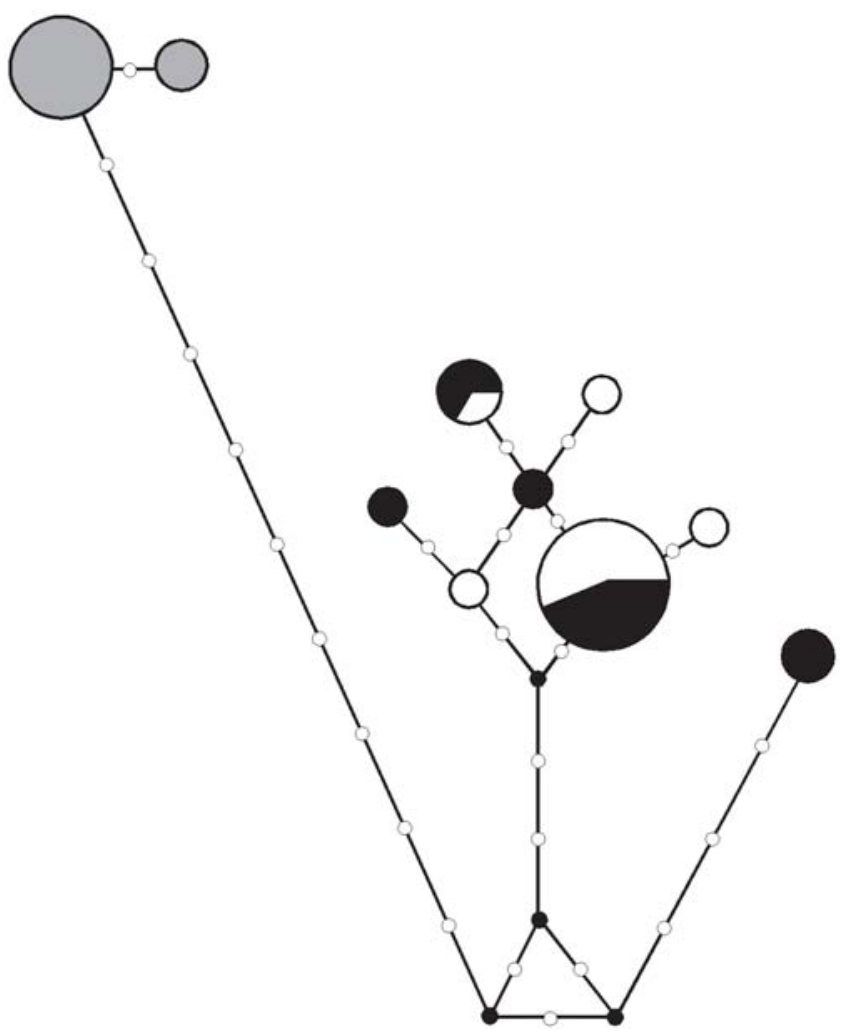

Fig. 4. Minimum spanning network of Ixinandria steinbachi haplotypes. Distances correlate to the number of mutations in the sequence as marked by open dots. Circle size corresponds to frequency of haplotypes. White: Juramento, black: Bermejo 1, grey: Bermejo 2.

has wide and almost symmetrical tooth cusps, and up to 18 teeth in each premaxilla ( $v s$. premaxilla with up to 13 narrow and clearly asymmetrical teeth in other loricariines, except Rineloricaria aequalicuspis which has up to 15 narrow teeth with nearly symmetrical cusps, and some hartiini, which also have many asymmetrical premaxillary teeth).

\section{Ixinandria steinbachi (Regan, 1906)}

Fig. 5

Loricaria steinbachi Regan, 1906: 97. Type locality: Salta, Argentina. - Eigenmann, 1911: 414 (listed under subgenus Rhineloricaria). - Pozzi, 1945: 275 (Jujuy). - Arratia et al., 1983: 54 and 82 (Jujuy; río Bermejo). - Arratia \& Menu Marque, 1984: 517 (reference).

Loricaria (Rhineloricaria) steinbachi. - Gosline, 1945: 102 [listed]. - Gomes, 1947: 24 [reference]. - Ringuelet \& Arámburu, 1962: 53 [Argentina]. - Ringuelet et al., 1967: 411, 413 [description and distribution in Argentina].

Ixinandria steinbachi. - Isbrücker, 1979: 91, 113 [new combination, lectotype designation]. - Isbrücker, 1980: 103 [reference]. - Isbrücker, $1981 \mathrm{a}$ : VI,75 [reference, discussion]. Isbrücker, 1981b: 89 [reference]. - López et al., 1987: 31 [listed, Argentina]. - Burgess, 1989: 417 [reference]. Fernández, 1996: 22 [Ledesma, Jujuy and Rosario de Lerma, 
Salta]. - Monasterio de Gonzo et al., 1998: 133-139 [trophic ecology]. - Isbrücker, 2001: 29 [reference]. - Nieva et al., 2001: 85 [La Ciénaga, río Arias, río Juramento basin, Salta]. - Barros et al., 2001: 9 [density in the río Arenales, Salta]. - Monasterio de Gonzo, 2002: 11-18 [description and comparision of dentition of three loricariids]. - López et al., 2002: 7 \& 60 [endemism in the Subtropical Potamic Axis ecoregion]. - López et al., 2003: 45 [listed]. - Ferraris, 2003: 336 [listed]. - Menni, 2004: 195, 198 [río Aguas Negras, Ledesma, Jujuy, and río Rosario at $48 \mathrm{~km}$ of Salta, habitat]. - Monasterio de Gonzo, 2003: 191-192 [distribution and redescription]. - Menni et al., 2005: 34, 38 [río Aguas Negras and río Juramento basin]. - López \& Miquelarena, 2005: 530, 534 [Paranoplatensean distribution, endemism in western South America]. - Monasterio de Gonzo et al., 2005: 36-41 [abundance and detritivourous trophic habits in río Popayán, Parque Nacional el Rey, Salta]. - Monasterio de Gonzo et al., 2005: 26 [distribution, listed to río Bermejo, río Juramento and río Dorado del Valle]. - Liotta, 2006: 365 [distribution]. - Covain \& Fisch-Müller, 2007: 31 [distribution, habitat, sexual dimorphism, and reproductive habits]. - Ferraris, 2007: 263 [listed, distribution, and remarks].

Canthopomus montebelloi Fowler, 1940: 55, fig. 10 [NEW SYNONYM]. Type locality: Monte Bello, Tarija, Bolivia. Böhlke, 1984: 123 [type catalog]. - Gosline, 1945: 83 [listed]. - Gosline, 1947: 108 [reference].
Ixinandria montebelloi. - Isbrücker, 1979: 87 [new combination]. - Isbrücker, 1980: 103 [reference]. - Isbrücker, 1981a: VI,75 [reference, discussion]. - Burgess, 1989: 417 [reference]. - Isbrücker, 2001:29 [reference]. - Ferraris, 2003: 336 [reference]. - Armbruster, 2004: 46, 66 \& 68 [phylogeny of family Loricariidae]. - López \& Miquelarena, 2005: 534 [endemism in western South America]. - Ferraris, 2007: 263 [listed, distribution].

Diagnosis. As for the genus

Description. Morphometric data in Table 1. Head and body strongly depressed. Trunk and caudal peduncle becoming more compressed caudally. Dorsal profile of body convex from snout to end of supraoccipital, straight or slightly convex from supraoccipital to dorsal-fin spine, straight from dorsal fin to one or two plates before caudal fin. Upper edge of orbit not raised. Scarcely developed triangular postorbital notch.

Outline of head rounded in dorsal view. Head strongly flattened in mature males. Paired anterior postrostral and cheek plates scarcely developed ventrally. Odontodes curved, conical, and pointed, densely covering head, trunk, and fin rays, making fish somewhat hispid. Body odontodes scarcely distributed and grouped centrally in plates (Fig. 6). Thick skin sometimes covering plates partially, hiding plate limits and covering odontodes. Snout tip with big globular protuber-

Table 1. Descriptive morphometrics of Ixinandria steinbachi of four distinct populations. Values are given as percents of standard length or of head length. Lec = Lectotype of Loricaria steinbachi, SD = standard deviation.

\begin{tabular}{|c|c|c|c|c|c|c|c|c|c|c|c|c|c|c|c|c|}
\hline \multirow[b]{2}{*}{ Character } & \multicolumn{5}{|c|}{ río Juramento basin $n=16$} & \multicolumn{4}{|c|}{ río Bermejo Argentina $n=18$} & \multicolumn{4}{|c|}{ río Bermejo Bolivia $n=37$} & \multicolumn{3}{|c|}{ río Pilcomayo $n=2$} \\
\hline & Lec & Low & High & Mean & SD & Low & High & Mean & $\mathrm{SD}$ & Low & High & Mean & SD & Low & High & Mean \\
\hline Standard length (mm) & 84.5 & 58.16 & 91.6 & 75.0 & - & 56.37 & 112.8 & 76.5 & - & 68.9 & 100.3 & 82.0 & - & 72.7 & 76.6 & 74.7 \\
\hline \multicolumn{17}{|c|}{ Percents of standard length } \\
\hline Predorsal length & 41.5 & 39.3 & 42.3 & 40.6 & 0.98 & 36.4 & 42.5 & 40.0 & 1.55 & 38.2 & 43.0 & 40.9 & 1.25 & 38.5 & 42.1 & 40.3 \\
\hline Postdorsal length & 61.0 & 57.5 & 63.4 & 61.3 & 1.59 & 59.8 & 64.9 & 62.3 & 1.41 & 59.3 & 65.0 & 62.2 & 1.43 & 60.7 & 63.3 & 62.0 \\
\hline Postanal length & 42.5 & 40.9 & 47.9 & 44.8 & 1.95 & 43.2 & 49.0 & 46.1 & 1.64 & 40.7 & 48.3 & 44.7 & 1.63 & 45.0 & 47.3 & 46.1 \\
\hline Dorsal-fin spine length & 21.3 & 19.1 & 23.8 & 21.7 & 1.38 & 17.9 & 26.1 & 22.3 & 1.82 & 18.1 & 24.6 & 21.1 & 1.63 & 20.0 & 23.5 & 21.8 \\
\hline Anal-fin spine length & 18.3 & 16.8 & 19.6 & 18.3 & 0.93 & 15.8 & 22.7 & 19.3 & 1.48 & 14.6 & 20.4 & 17.6 & 1.30 & 16.0 & 18.8 & 17.4 \\
\hline Pectoral-fin spine length & 21.9 & 19.1 & 23.1 & 20.8 & 1.24 & 15.9 & 23.8 & 20.7 & 1.94 & 16.6 & 22.7 & 20.1 & 1.65 & 19.0 & 21.7 & 20.4 \\
\hline Pelvic-fin spine length & 21.2 & 17.9 & 21.2 & 19.3 & 0.91 & 15.7 & 21.7 & 19.0 & 1.47 & 16.6 & 21.6 & 19.4 & 1.21 & 17.1 & 19.4 & 18.2 \\
\hline Uppermost caudal-fin ray & 16.7 & 14.1 & 19.9 & 15.5 & 4.38 & 15.7 & 21.4 & 18.1 & 1.42 & 14.0 & 19.9 & 17.0 & 1.52 & 14.4 & 15.5 & 15.0 \\
\hline Lowermost caudal-fin ray & 16.7 & 14.0 & 18.8 & 13.8 & 5.53 & 13.9 & 19.6 & 16.9 & 1.55 & 13.6 & 19.4 & 16.3 & 1.18 & 14.0 & 15.3 & 14.6 \\
\hline Thoracic length & 22.5 & 16.1 & 22.5 & 18.7 & 1.69 & 16.1 & 19.2 & 18.1 & 0.77 & 16.3 & 21.3 & 18.3 & 1.31 & 17.2 & 19.1 & 18.2 \\
\hline Abdominal length & 18.7 & 16.4 & 21.1 & 18.9 & 1.27 & 17.1 & 22.1 & 19.3 & 1.32 & 17.7 & 22.0 & 19.9 & 1.23 & 20.1 & 20.1 & 20.1 \\
\hline Cleithral width & 24.5 & 22.0 & 25.8 & 24.2 & 1.00 & 21.8 & 25.6 & 23.9 & 1.16 & 22.4 & 27.6 & 24.8 & 1.25 & 23.3 & 26.4 & 24.9 \\
\hline Depth of caudal peduncle & 3.4 & 2.3 & 3.4 & 2.8 & 0.26 & 2.3 & 3.2 & 2.7 & 0.23 & 2.5 & 3.8 & 3.0 & 0.28 & 2.7 & 2.8 & 2.8 \\
\hline Width of caudal peduncle & 5.1 & 4.2 & 5.9 & 5.0 & 0.46 & 4.3 & 5.6 & 4.8 & 0.39 & 4.1 & 5.9 & 5.0 & 0.38 & 4.3 & 4.7 & 4.5 \\
\hline Pelvic-fin origin to caudal-fin & 59.4 & 59.4 & 65.4 & 62.7 & 1.71 & 61.7 & 68.1 & 64.7 & 1.65 & 58.8 & 69.1 & 63.2 & 2.23 & 65.7 & 67.0 & 66.4 \\
\hline Snout tip to pelvic-fin origin & 43.2 & 36.1 & 43.2 & 38.6 & 2.19 & 34.7 & 42.0 & 37.0 & 1.69 & 34.1 & 42.0 & 38.2 & 1.79 & 35.2 & 36.3 & 35.7 \\
\hline Body width at dorsal fin origin & 21.3 & 17.3 & 24.0 & 21.3 & 1.93 & 16.8 & 24.8 & 20.5 & 1.74 & 18.9 & 28.5 & 23.2 & 2.27 & 19.1 & 19.8 & 19.4 \\
\hline Body depth at dorsal fin origin & - & 12.3 & 17.3 & 14.1 & 4.12 & 10.0 & 18.4 & 15.6 & 2.07 & 12.2 & 21.3 & 16.9 & 2.20 & 14.1 & 14.6 & 14.3 \\
\hline Body width at anal-fin origin & 14.2 & 13.2 & 16.6 & 14.8 & 1.04 & 11.1 & 15.7 & 14.1 & 1.26 & 13.5 & 19.7 & 15.7 & 1.33 & 14.2 & 14.2 & 14.2 \\
\hline Body depth at anal-fin origin & 9.9 & 9.8 & 12.9 & 10.8 & 0.73 & 9.8 & 16.6 & 11.3 & 1.77 & 10.1 & 12.6 & 11.3 & 0.60 & 9.7 & 10.7 & 10.2 \\
\hline Head length & 28.7 & 26.0 & 28.7 & 27.1 & 0.93 & 24.9 & 29.0 & 26.6 & 0.98 & 24.2 & 29.8 & 27.4 & 1.24 & 25.4 & 26.8 & 26.1 \\
\hline \multicolumn{17}{|c|}{ Percents of head length } \\
\hline Head depth & 50.1 & 45.5 & 61.4 & 53.7 & 4.59 & 50.7 & 64.3 & 55.3 & 3.62 & 45.6 & 65.6 & 55.7 & 4.67 & 48.2 & 50.3 & 49.3 \\
\hline Snout length & 57.5 & 50.3 & 59.6 & 54.7 & 2.64 & 51.5 & 56.3 & 54.8 & 1.36 & 49.7 & 62.2 & 55.6 & 2.26 & 52.3 & 56.2 & 54.2 \\
\hline Interorbital width & 31.3 & 25.3 & 31.3 & 28.8 & 1.61 & 25.8 & 30.3 & 28.7 & 1.48 & 25.0 & 30.3 & 27.4 & 1.06 & 28.2 & 28.3 & 28.3 \\
\hline Internareal width & 10.3 & 7.3 & 11.7 & 9.2 & 1.21 & 8.4 & 12.2 & 10.1 & 0.90 & 6.4 & 12.7 & 10.1 & 1.32 & 11.3 & 11.7 & 11.5 \\
\hline Orbit diameter including notch & 14.8 & 13.4 & 20.1 & 15.8 & 1.89 & 14.5 & 20.1 & 17.5 & 1.56 & 14.8 & 19.8 & 16.9 & 1.45 & 15.7 & 16.1 & 15.9 \\
\hline Orbit diameter excluding notch & 10.1 & 8.4 & 14.6 & 10.7 & 1.41 & 10.0 & 12.8 & 11.4 & 0.72 & 9.7 & 13.2 & 11.4 & 0.94 & 11.8 & 11.8 & 11.8 \\
\hline Premaxilary ramus & 17.6 & 13.3 & 17.9 & 15.9 & 1.41 & 14.8 & 18.8 & 16.9 & 1.02 & 13.9 & 19.5 & 17.0 & 1.24 & 16.8 & 17.6 & 17.2 \\
\hline Width of lower lip & 65.9 & 51.9 & 66.5 & 60.8 & 4.26 & 59.0 & 70.2 & 63.3 & 3.13 & 58.0 & 84.1 & 71.3 & 5.59 & 70.8 & 71.8 & 71.3 \\
\hline
\end{tabular}




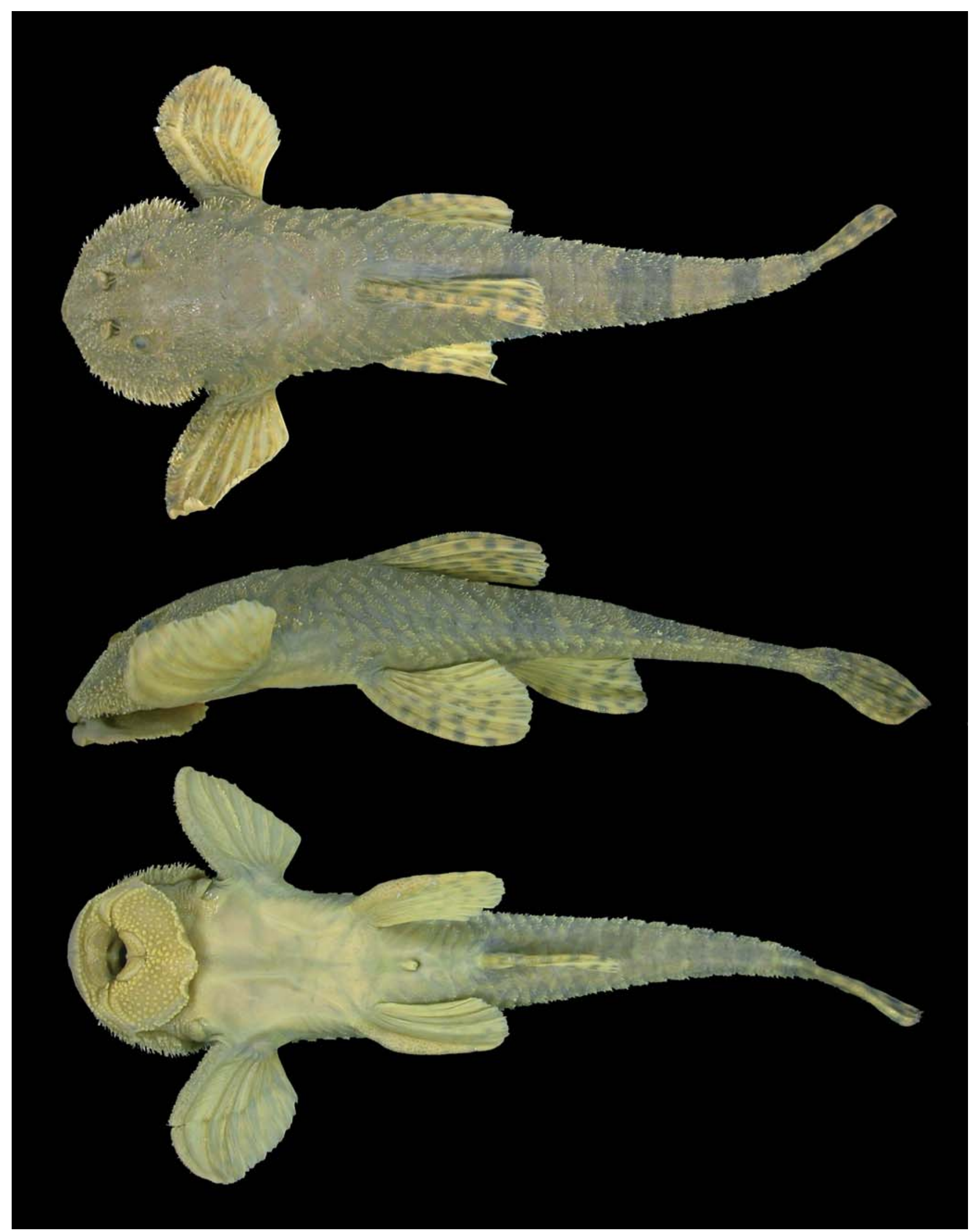

Fig. 5. Ixinandria steinbachi, UMSS 215, $100.3 \mathrm{~mm} \mathrm{SL}$, male, río Orosas, Aniceto Arce, Province of Tarija, río Bermejo basin, Bolivia. 


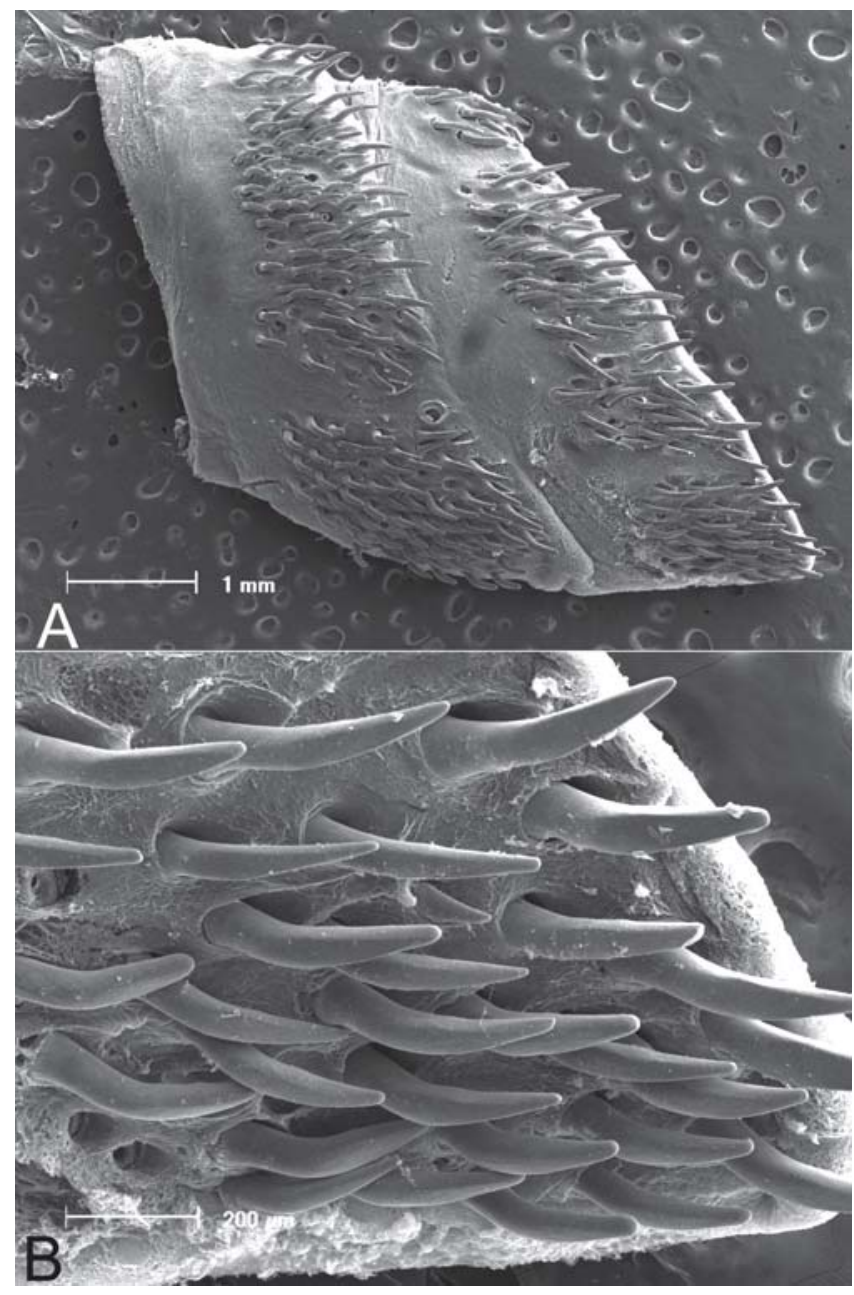

Fig. 6. Scanning electron micrographs of the body odontodes of Ixinandria steinbachi (MCNI 99, $65.9 \mathrm{~mm} \mathrm{SL).} \mathrm{A)} \mathrm{Two}$ plates of the median and mid-ventral lateral series with odontodes; B) detail of odontodes.

ance of naked skin. This roundish naked area not reaching most anterior pore of infra-orbital ramus of sensory canal. Gill opening small. Mouth big and roundish. Lower lip margin with short digitiform papillae. Upper lip well developed, folded inwards with row of globular papillae. Big globular papillae arranged in regular rows on surface of lips. Numerous small globular papillae on mouth roof, bigger posteriorly. Maxillary barbel very small, mostly coalesced with lower lip. Teeth bilobed, with wide cusps, mesial more developed and slightly longer than lateral (Fig. 7). Premaxilla with six to 18 (mean=12.4, $\mathrm{n}=71$ ) teeth in functional series. Dentary with six to 15 (mean=10.3, $\mathrm{n}=46$ ) teeth in functional series.

Abdomen completely naked, except for lateral abdominal plates. Preanal plate absent. Two to $11($ mean= 7.0, $n=72)$ lateral abdominal plates on each side. 27 to 32 (mean=29.4, $\mathrm{n}=72$ ) plates in median lateral series, with well developed keels formed by hypertrophied odontodes. Five lateral series, sometimes broken and appearing to have six or seven lateral series; only posterior portion of median and midventral series with keels. Keels coalesced in last seven to 12 rings (mean=9.5,

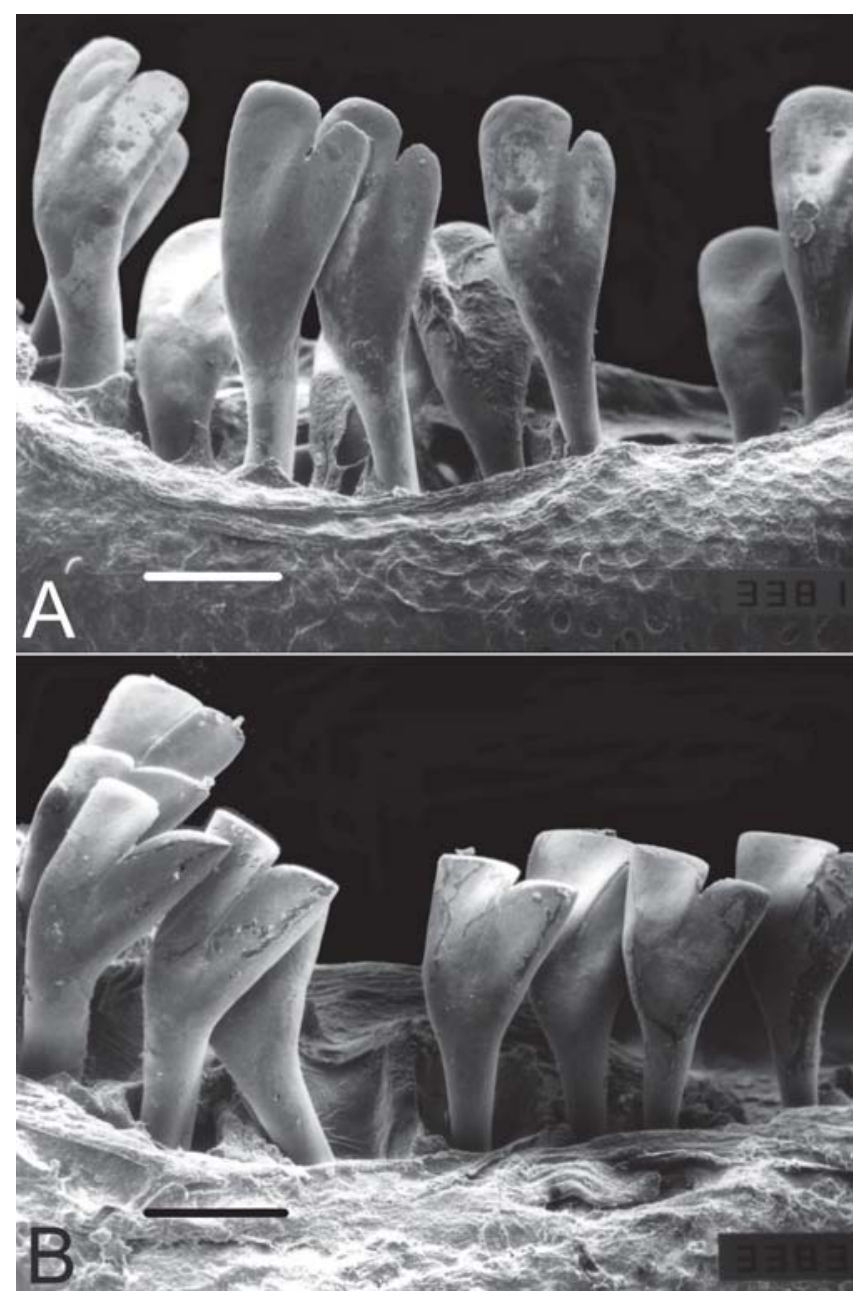

Fig. 7. Scanning electron micrographs of premaxilary teeth of Ixinandria steinbachi, showing sexual dimorphism in teeth cusps. A) MCNI 419, $69.3 \mathrm{~mm} \mathrm{SL}$, male; B) MCNI 419, $71.1 \mathrm{~mm}$ SL, female. Scale $700 \mu \mathrm{m}$.

$\mathrm{n}=72$ ). Middorsal series with 5-10 plates (mean=7.8, n=9) (better visible in cleared and stained material). Entire body with thick skin between the plates, especially in the lateral series. Predorsal plates usually arranged in irregular pattern, not forming rows. Supraoccipital and predorsal plates without keels. Transversal diameter of nasal capsule equal or slightly larger than eye diameter including notch (better visible in cleared and stained material).

Posterior margin of dorsal fin straight or slightly rounded, generally with first or second branched ray longest. Tip of dorsal fin, when depressed, reaching third or fourth (exceptionally fifth) plate posterior to fin insertion. Dorsal-fin spinelet absent. Posterior margin of pectoral fin convex, first or second branched ray longest, reaching to or slightly beyond pelvic-fin origin. Posterior margin of pelvic fin rounded; first or second branched ray longest, reaching to or falling slightly short of anal-fin origin. Posterior margin of anal fin rounded, with longest first or second (rarely) branched ray. Tip of anal fin, when depressed, reaching fifth or sixth plate posterior to fin insertion; three or four ventral plates along its base. Pos- 
terior margin of caudal fin truncated or slightly concave. Upper and lower unbranched rays never extending as filament. Two or three supracaudal plates covering base of caudal-fin rays, median plate sometimes absent.

Color in alcohol. Background color of dorsal surface of head and body dark brown with five darker transverse bars; first one inconspicuous on supraoccipital, others distributed between origin of dorsal fin and caudal fin. Last three bars sometimes continuing across ventral surface and forming dark brown rings. Some specimens with black spots on head and snout. Dorsal fin with dark gray circular spots. Pectoral and pelvic fins yellowish with dark circular spots. Sensorial pores on head and beginning of lateral canal pigmented with black. Ventral surface of body light brown in naked regions. Anal and caudal fins with dark dots arranged in bars on branched and unbranched rays. Ventral plates darkened around anal-fin base.

Color in life. Background color of head and body light brown with five dark brown transverse bars distributed as described above. Other markings as described above (Fig. 8).

Sexual dimorphism. Males with head wide and flattened; long hypertrophied odontodes on sides of head and on upper side of branched pectoral-fin rays; short odontodes on remaining of dorsal surface of body, especially on predorsal region; unbranched pectoral-fin ray hypertrophied. Papillae in mouth cavity more numerous in males than in females. Outer margin of tooth cusps straight in females, rounded in males (Fig. 7).

Ontogeny. Many structures vary ontogenetically in Ixinandria steinbachi. The premaxilla, dentary, and the pectoral girdle are ossified in a specimen of $17.2 \mathrm{~mm} \mathrm{SL}$, the smallest individual we were able to examine. At that size the pelvic girdle was not developed, the lateral abdominal plates and plates on the head and predorsal region were not formed. The lateral series of plates were represented by small platelets with one or two odontodes each.

In a specimen of $28.2 \mathrm{~mm} \mathrm{SL}$ the pelvic girdle, the lateral connecting bone, the nucal plate, and the neurocranium are totally ossified. The plates on the head are represented by scarce odontodes and the lateral series of plates are almost entirely formed from the posterior region to level of the dorsal fin. Three small lateral abdominal plates are forming laterally on the abdomen, with one or few odontodes each.

Distribution and habitat. Upper río Juramento basin, río Salado drainage in Salta (Argentina), upper río Bermejo in northwestern Argentina and southern Bolivia, and upper río Pilcomayo in southern Bolivia (Fig. 9). Its presence in the río Pilcomayo is herein reported for the first time. Ixinandria steinbachi was caught in fast flowing waters between 15 and $65 \mathrm{~cm}$ depth, especially in places with filamentous algae, in mountainous areas at altitudes ranging from around 200 to 2900 meters a.s.1. The minimun altitude where it was recorded is $210 \mathrm{~m}$ a.s.l. in the río Rosario, $48 \mathrm{~km}$ from the city of Salta. This

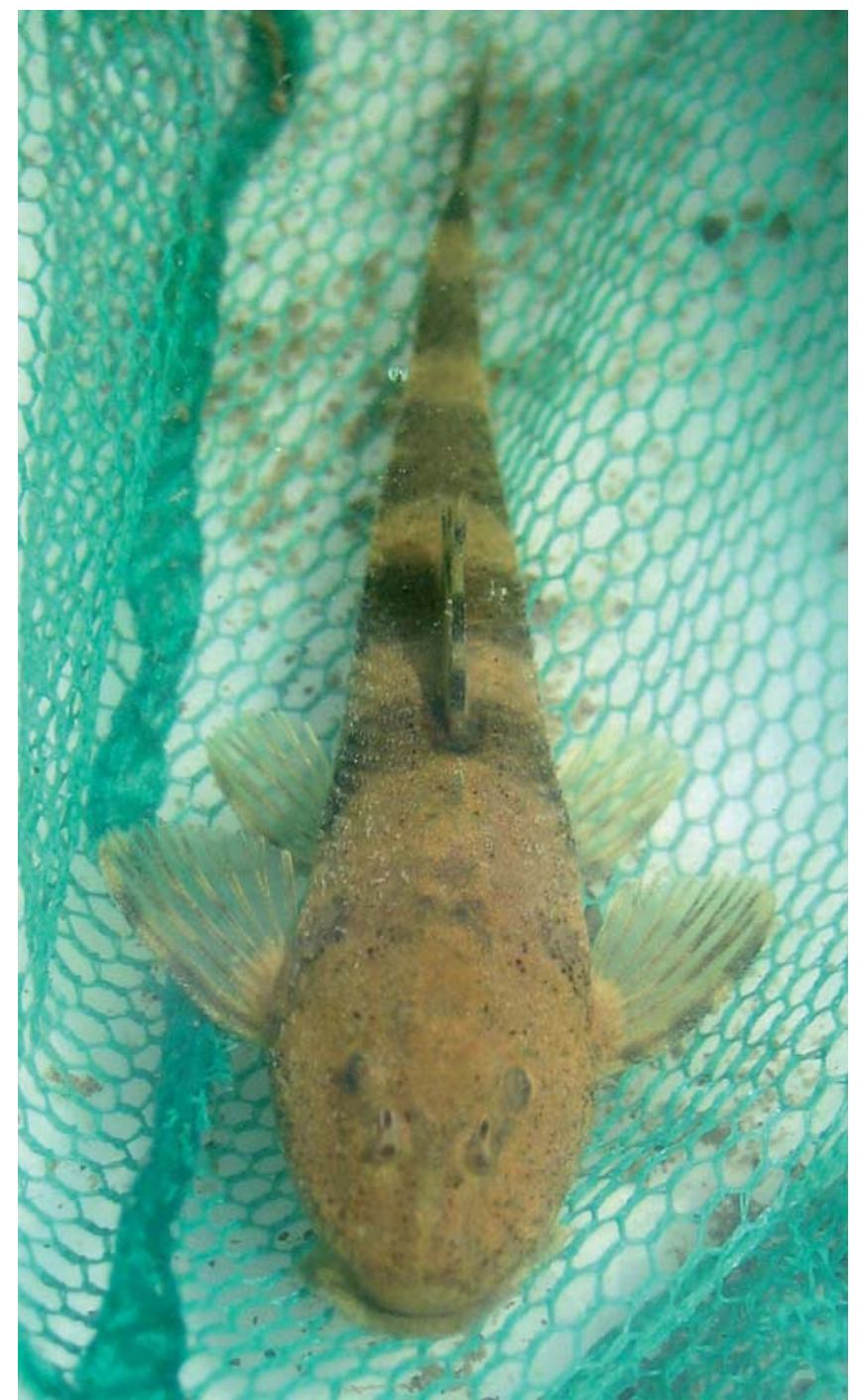

Fig. 8. Living specimen of Ixinandria steinbachi from the río Arenales near Salta, Argentina, November 2007. Photo by CAC.

species lives in fast flowing and highly oxygenated waters, with stony bottom, usually hiding under the stones during the day. Under $2200 \mathrm{~m}$ a.s.l. one species of Hypostomus, Heptapterus mustelinus, and some characids and other loricarids were found occurring syntopically with I. steinbachi (Menni, 2004).

\section{Discussion}

The principal components analysis of morphometric traits failed to discriminate clusters among the four populations of Ixinandria being investigated, indicating that morphology is highly homogeneous and suggesting no species-level separation. However, small morphological differences were found between specimens of populations from the río Bermejo in southern Bolivia and the río Bermejo in Argentina (Baritú National Park) when compared to specimens from other tributaries to the río Bermejo and río Juramento basins in Argentina. These 


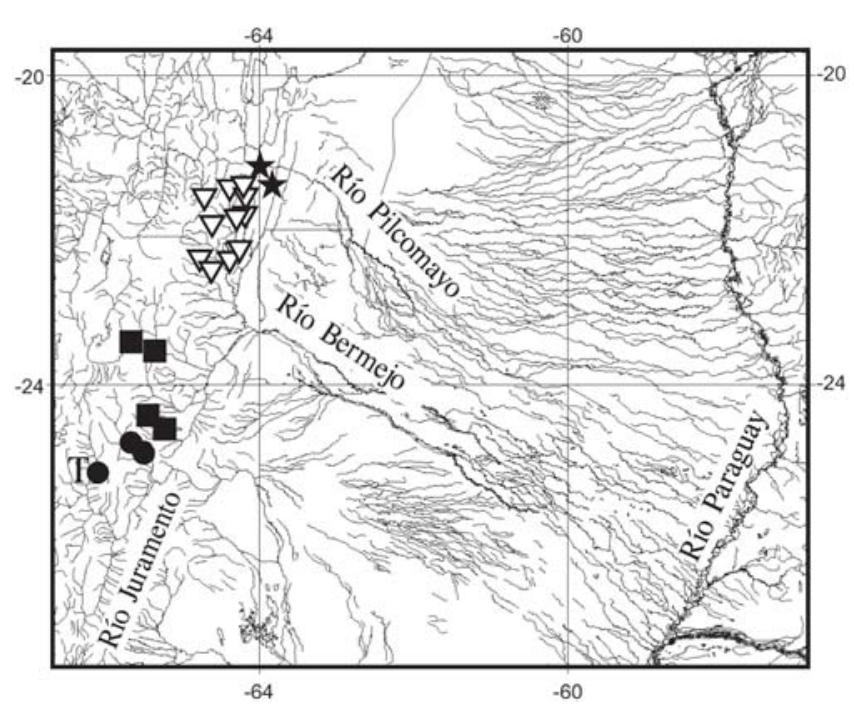

Fig. 9. Distribution of Ixinandria steinbachi. Dot, río Juramento basin; Square, southern upper río Bermejo drainage; triangle, northern upper río Bermejo basin; and Star, río Pilcomayo. Each symbol can represent more than one lote or locality. ( $\mathrm{T}=$ Type locality).

small differences are degree of development of odontodes along the sides of the head in mature males, width of the pectoral-fin spine, and size of the naked skin area at the tip of the snout. These differences, however, are difficult to interpret and mostly overlap when many specimens are analysed, and are not enough to warrant species level separation.

The molecular analysis was similarly not able to discriminate the population from the upper río Juramento basin, type locality of Ixinandria steinbachi, from that in the the upper río Bermejo in Salta, Argentina. A significant difference, however, was found between the population in the río Bermejo in Salta and that in the tributaries to the same river in Tarija, Bolivia, type locality of Ixinandria montebelloi. This difference, however, is smaller than those usually found among species clearly distinct and is not enough to warrant separate species recognition. The mean K2P distance between our sequences was $1.1 \%$, which falls within the typical range of intraspecific $\mathrm{K} 2 \mathrm{P}$ distance in COI sequences of up to $2 \%$, much smaller than the average distance of $9.9 \%$ of distinct, congeneric species (Ward et al., 2005).

An explanation for the differences found could be that the samples represent three separate populations of the same species, what corroborates the morphologic results. The differences between the populations from the río Bermejo in Salta and in Tarija could be explained by the geographic distance $(>350 \mathrm{~km})$ between the two sample localities. To test this hypothesis, samples from areas between the present collection stations and from the río Pilcomayo basin would be necessary. In summary, the results of the molecular analysis do not adequately support the discrimination of the populations and therefore the separation of the two species.

Both morphometric and molecular results make sense from the geological point of view. Andean orogeny and climate have had profound influence on the biota of the Central Cor- dillera in northeastern Argentina and southern Bolivia. The geological and climatic development during the late Tertiary and early Quaternary have had a significant impact on the establishment of orographic barriers and the regulation and distribution of rain in this region and, as a consequence, on the establishment and continous changing of hydrographic drainages (Alonso et al., 2006).

The presence of a single species of Ixinandria in the three river drainage basins can be explained by the fact that the Pilcomayo, Bermejo, and Juramento rivers had been connected and separated several times during the Quaternary, as indicated by the superposition of their alluvial fans (Iriondo, 1993). One example of documented river capture is the río La Caldera, presently a tributary to the río Bermejo basin that formerly used to cross the area where today the city of Salta is located draining towards the south and emptying into the río Arenales, itself a tributary to the río Juramento (Monasterio de Gonzo, 2003). Because of early Quaternary tectonism the río La Cardera changed its direction and become a tributary to the río Mojotoro, in the upper río Bermejo basin. A considerable similarity in the catfish fauna between the río Juramento and the río Bermejo drainage basins was reported by Monasterio de Gonzo et al. (1994). The geographic distribution of Ixinandria steinbachi, encompassing the upper portions of the Pilcomayo, Bermejo, and Juramento rivers, is very similar to the distributions of Parodon carrikeri, Oligosarcus bolivianus, Corydoras micracanthus, Loricaria tucumanensis (Liotta, 2006), and Jenynsia alternimaculata (Ghedotti, 1998).

The only citation of Ixinandria steinbachi for a river outside the known range of the species is that of Gomes (1947), who listed a species of Rineloricaria from the rio Maquiné in northeastern Rio Grande do Sul State, southern Brazil, as Loricaria (Rhineloricaria) steinbachi, based on 18 young specimens deposited at the UMMZ. That species was later found to be new and described as Rineloricaria aequalicuspis by Reis \& Cardoso (2001).

The diagnosis of Ixinandria is based on a completely naked abdomen, which has no abdominal plates ventral to the lateral abdominal plates. Only one specimen out of 242 examined in this study, from the río Juramento basin (MCNI 1225), has small platelets on the central portion of the abdomen. Even in this specimen, a preanal plate is lacking. The validity of the genus Ixinandria is a question beyond the scope of this study, and will remain unanswered until a broad phylogenetic analysis of the loricariines can be performed.

\section{Acknowledgements}

Thanks are due to Gladys Monasterio de Gonzo (MCNI), Fernando Carvajal (UMSS), Lucila Protogino (ILPLA), James Maclaine (BMNH), John Lundberg and Mark Sabaj (ANSP), Mary Anne Rogers and Kevin Swagel (FMNH), William Fink, Sara Fink and Douglas Nelson (UMMZ), Richard Vari and Jeffrey Williams (USNM) for the loan of material, photos, and cordiality during the visits to the different institutions. Spe- 
cial thanks are due to Gladys and Fernando who sent a lot of fixed material and tissue from Argentina and Bolivia for this study. Virginia Martinez and Gastón Aguilera helped collecting fishes. Ricardo Kanitz helped with the genetic programs. Tiago Carvalho took the scanning electron micrographs at PUCRS. MSR was financed by a fellowship from Universidad Nacional de La Plata (UNLP) and by a postdoctoral fellowship from CONICET/CNPq. The All Catfish Species Inventory (NSF-DEB \#0315963) subsidized the visit of MSR to the North American museums. CAC was financed by a two-years doctoral fellowship from the German Academic Exchange Service (DAAD) and a one year doctoral fellowship from CNPq. RER is partially financed by CNPq (process \# 301748/2004-7). SLB is partially financed by CNPq (process \# 481121/2004-8).

Material examined. Ixinandria steinbachi. Argentina: Salta: río Juramento basin: BMNH 1906.5.31.37 (84.5 mm SL), lectotype, Departamento Cachi, elevation 2,500m a.s.1. (25 06' $15^{\prime \prime S}$ 66'11'16"W). BMNH 1906.5.31.38-39 (2, 58.2-66.4 mm SL), paralectotypes, same data as lectotype. MCNI 99, 10+2 c\&s, 56.291.6 mm SL (9, 71.7-91.6 mm SL), río Calchaqui, Departamento Cachi (2507'30"S 6609'57"W). MCNI 419, (4, 69.1-76.6 mm $\mathrm{SL})$, río Arenales at field station 2, Departamento Capital (24\%48'34"S $\left.65^{\circ} 25^{\prime} 18^{\prime \prime} \mathrm{W}\right)$. MCNI 854, 4, 75.2-85.0 mm SL, río Calchaqui,

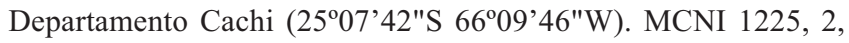
75.6-77.3 mm SL, río Arenales, Departamento Capital, elevation 1219 m a.s.1., (24\% $\left.47^{\prime} 43.9^{\prime \prime S} 65^{\circ} 28^{\prime} 2.5^{\prime \prime W}\right)$. MCP 41303, 27+5 c\&s, 33.9-69.9 mm SL, río Arenales, Departamento Capital (approx.

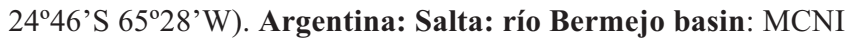
186, 1, $68.2 \mathrm{~mm}$, río Mojotoro, Departamento La Caldera (approx. $\left.24^{\circ} 41^{\prime} \mathrm{S} 65^{\circ} 17^{\prime} \mathrm{W}\right)$. MCNI 198, 6, 61.4-91.5 mm SL (2, 74.8-87.4 $\mathrm{mm}$ SL), El Gallinato, Departamento La Caldera (25\%41'00.9"S 65ำ 18 '48.7"W). MCNI 220, 3, 58.7-73.5 mm SL (2, 59.5-74.3 mm $\mathrm{SL}$ ), río La Caldera, Departamento La Caldera (approx. $24^{\circ} 41^{\prime} \mathrm{S}$ 65²17'W). MCNI 331 (2 c\&s, 56.4-60.6 mm SL), río Mojotoro, Departamento La Caldera (24ㄴㄹ' $\left.21^{\prime \prime S} 65^{\circ} 15^{\prime} 16^{\prime \prime W}\right)$. MCNI 415, (1, $76.4 \mathrm{~mm} \mathrm{SL})$ and MCP 41918, 6, 39.5- 89.4 mm SL (2, 69.389.4 mm SL), río La Caldera, Departamento La Caldera (24³6'22"S 65²2’39"W). MCNI 519, 12, 58.8-74.0 mm SL, río La Caldera, Departamento La Caldera (approx. 24³7'S 6523'W). MCNI 585 (4, 73.8-112.8 mm SL), río Castellanos, Departamento Capital (244ㄴ'58"S 65²8'45"W). MCNI 1122, 5, 65.3-78.9 mm SL, río

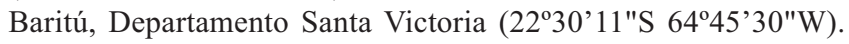
MCNI 1130, 2, 89.1-100.7 mm SL, arroyo Vallecito, Departamento Santa Victoria (22 $\left.20^{\circ} 00^{\prime \prime S} 64^{\circ} 45^{\prime} 21^{\prime \prime W}\right)$. Argentina: Jujuy: río Bermejo basin: ILPLA 1677, 4, 40.2-85.8 mm SL (2, 78.1-85.8 $\mathrm{mm} \mathrm{SL}$ ) creek tributary to río Grande near Tilcara (approx. 23³4'S $\left.65^{\circ} 22^{\prime} \mathrm{W}\right)$. ILPLA 1678, (2, 71.7-86.8 mm SL), río Grande north of Tilcara (approx. $23^{\circ} 25^{\prime} \mathrm{S} 65^{\circ} 44^{\prime} \mathrm{W}$ ). MACN-Ict 3157, 9, 26.6-94.5 $\mathrm{mm}$ SL, río Grande. Bolivia: Tarija Province: río Bermejo basin: ANSP 68832, 1, $72.9 \mathrm{~mm}$ SL, holotype of Canthopomus montebelloi (not measured for morphometric comparisons because of bad state of preservation), Monte Bello, río Bermejo. UMSS 210, 4, 27.6-68.8 mm SL, río Salinas, O’Connor (21³8'42"S 649'8"W). UMSS 211, 12, 24.8-69.8 mm SL (1, 69.7 mm SL), río Say Kan, O'Connor (21 $\left.{ }^{\circ} 46^{\prime} 27^{\prime \prime S} 64^{\circ} 5^{\prime} 24^{\prime \prime W}\right)$. UMSS 214, $41+1$ c\&s, 35.3-89.4 mm SL (14, 68.9-89.4 mm SL), río Emborozú (21 $\left.{ }^{\circ} 56^{\prime} 08^{\prime \prime S} 64^{\circ} 41^{\prime} 21^{\prime \prime} \mathrm{W}\right)$. UMSS 215, $22+6$ c\&s. 16.8-100.5 mm SL (10, 82.1-100.3 mm SL), río Orosas, Aniceto Arce (21 ${ }^{\circ} 56^{\prime} 8^{\prime \prime} \mathrm{S}$ $\left.64^{\circ} 41^{\prime} 21^{\prime \prime W}\right)$. UMSS 216, 7, 46.2-77.3 mm SL (2, 76.1-76.7 mm
SL), río Cuesta Vieja, O’Connor (212 $\left.25^{\prime} 17^{\prime \prime S} 64^{\circ} 16^{\prime} 39^{\prime \prime W}\right)$. USNM 314303, 1, $44.9 \mathrm{~mm}$ SL, río Salinas, $3 \mathrm{~km} \mathrm{~S}$ of Entre Rios (approx. $\left.21^{\circ} 33^{\prime} \mathrm{S} 64^{\circ} 10^{\prime} \mathrm{W}\right)$. USNM 314300, 17, 35.4-94.3 mm SL (5, 72.5$94.3 \mathrm{~mm} \mathrm{SL}$ ), río Guadalquivir, tributary to río Tarija ca. $5 \mathrm{~km} \mathrm{NW}$ Tarija (approx. 2130'S 6446' W). CBF 6069, 2, 70.6-73.7 mm SL $(1,73.7 \mathrm{~mm} \mathrm{SL})$, río La Planchada, tributary to río Conchas, Tariquia, Arce (22 $\left.{ }^{\circ} 17^{\prime} 15^{\prime \prime S} 64^{\circ} 23^{\prime} 30^{\prime \prime W}\right)$. CBF 6071, 2, 42.9-69,7 mm SL, río Conchas, Tariquia, Arce (approx. $22^{\circ} 22^{\prime}$ S $64^{\circ} 24^{\prime} \mathrm{W}$ ). CBF 6100 , 6, 34.6-92.1 mm SL (2, 69.0-92.1 mm SL), arroyo La Misión, Tariquia, Arce (approx. $\left.21^{\circ} 48^{\prime} \mathrm{S} 64^{\circ} 17^{\prime} \mathrm{W}\right)$. CBF 6106, 2, 62.0-71.6 mm SL, creek near Arémbolo, Tariquia Arce (2149'49"S 64¹4'59"W). CBF 6137 (2, 73.2-73.6 mm SL), arroyo Barrial, tributary to río Chuquisaca, Entre Rios, O'Connor (21 53 '30"S 64' $\left.{ }^{\prime} 15^{\prime \prime} \mathrm{W}\right)$. Bolivia: Tarija Province: río Pilcomayo basin: UMSS 212 (1, $72.7 \mathrm{~mm} \mathrm{SL}$ ), río Serere, O'Connor (2126'54"S $\left.64^{\circ} 5^{\prime} 58^{\prime \prime W}\right)$. UMSS $213(1,76.6 \mathrm{~mm} \mathrm{SL})$, río Saladito, O’Connor $\left(21^{\circ} 18^{\prime} 29^{\prime \prime S} 64^{\circ} 7^{\prime} 2^{\prime \prime} \mathrm{W}\right)$.

Comparative material. Crossoloricaria venezuelae: UMMZ 141938, 6 paratypes, río Socuy, $3 \mathrm{~km}$ above mouth north of Maracaibo, Venezuela. Dasyloricaria capetensis: FMNH 7582, holotype and USNM 78340, 1 paratype, río Capeti, Panamá. Dasyloricaria filamentosa: FMNH 55114, 1 syntype, Calamar, Colombia; FMNH 55115, 7 syntypes and USNM 79219, 1 syntype, Boca de Certegui, Colombia. Dasyloricaria tuyrensis: FMNH 7583, holotype, FMNH 29317-18, 2 paratypes and USNM 78341, 3 paratypes, río Tuyra, Boca de Cupe, Darien, Panama. Dasyloricaria seminuda: FMNH 55116, 2 syntypes, Soplaviento, Colômbia; FMNH 55113, syntype?, Colômbia. Fonchiiichthys rupestris: UMMZ 141939, 6 paratypes, río San Juan above bridge south of Mene Grande, Motatan System, Venezuela. Harttia kronei: MCP 20148, $22+2$ c\&s, rio Piedade on road from Rio Branco do Sul to Açungui ca. $26 \mathrm{~km}$ NNW of Rio Branco do Sul, rio Ribeira drainage, Rio Branco do Sul, Paraná, Brazil (2500’42"S 49²0’20"W). Hemiloricaria altipinnis: AMNH 8404, holotype, río Chico, Panama. Hemiloricaria fallax: ANSP 177288, 10, Essequibo River, extensive sandbar $2 \mathrm{~km}$ upstream from Paddle Rock campsite, Guyana (approx. $04^{\circ} 42^{\prime} \mathrm{N} 58^{\circ} 42^{\prime} \mathrm{W}$ ); ANSP 175898 , 3, clear water creek at campsite 3.1 miles from Kurupukari field station on Kurupukari-Suranama river road (approx. $04^{\circ} 38^{\prime} \mathrm{N} 58^{\circ} 42^{\prime} \mathrm{W}$ ). Hemiloricaria morrowi: ANSP 68663, holotype, río Ucayali basin near Cantamana, Peru. Hemiloricaria parva: ANSP 53892, 1, Descalvados, Mato Grosso, Brazil. Rineloricaria malabarbai: MCP 9801,1 paratype, arroio Fão, Lageado, Rio Grande do Sul, Brazil; MCP 9848, 1 paratype, rio Pardinho, Santa Cruz do Sul, Rio Grande do Sul, Brazil. Rineloricaria misionera: MCP 35793, 3 paratypes, arroyo Liso, Cuña-Pirú valley, Departamento Cainguás, Misiones, Argentina. Rineloricaria pareiacantha: ANSP 67815, holotype, río Santa Lucia, Canelones, Uruguay. Spatuloricaria caquetae: ANSP 70527, 1 paratype, río Orteguasa, Florencia, Provincia Caqueta, Colombia. Spatuloricaria evansii: ANSP 180486, 1, río Yanatili near confluence with río Urubamba and town of Quello Uno, Cuzco, Peru (approx. 12³8'S $\left.72^{\circ} 33^{\prime} \mathrm{W}\right)$. Spatuloricaria fimbriata: FMNH 55117, holotype and FMNH 55118, 1 paratype, Boca de Certegui, Colômbia. Spatuloricaria gymnogaster: FMNH 55138, 29 paratypes, Colombia; UMMZ 141937, 15 paratypes, río Motatán, at bridge $22 \mathrm{~km} \mathrm{~N}$ of Motatán, Venezuela. Spatuloricaria lagoichthys: FMNH 42792, 5 and USNM 121097, 43 paratypes, río Socuy $3 \mathrm{~km}$ above mouth, río Maracaibo basin, Venezuela. Spatuloricaria puganensis: FMNH 84109, 1, río San Alejandro, Peru; FMNH 84127, 2, río Sungaro Yacu, ca 2.75 hrs upstream junction of río Sungaro Yacu and río Pachitea, Peru. 
Genbank and depository information for specimens included in the molecular analysis. Ixinandria steinbachi: Argentina, río Juramento basin: Juramento 1: MCNI 1222, 7, río Arenales, Departamento Capital (24 $47^{\prime} 43.9^{\prime \prime} \mathrm{S} 65^{\circ} 28^{\prime} 02.5^{\prime \prime} \mathrm{W}$, elevation 1185 m a.s.1) (Genbank codes EU359426, EU559056, EU559057, EU559059, EU559060, EU559061, and EU559062). Juramento 2: MCNI 1382, 5, río Arenales, Departamento Capital (2448'37"S 65'25'10.9"W, elevation 1185 m a.s.l) (Genbank codes EU559055, EU559058, EU559063, EU559064, and EU559065). Argentina, río Bermejo basin: Bermejo 1.1: MCNI 1287, 7, río La Caldera (244ㄴ'21.2"S 65²3'29.8"W, elevation 1252 m a.s.1.) (EU559066, EU359424, EU559067, EU559068, EU559069, EU559070, and EU559071). Bermejo 1.2: MCNI 1286, 4, arroyo Lesser

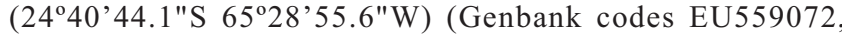
EU559073, EU559074, and EU559075). Bolivia, río Bermejo basin: Bermejo 2.1: UMSS GEN1707, 1, UMSS GEN1708, 1, UMSS GEN1709, 1, UMSS GEN1710, 1, and UMSS GEN1711, 1, río Gaudalquivir, tributary to río Tarija, San Lorenzo, Mendez Province $\left(21^{\circ} 22^{\prime} 23.9^{\prime \prime S} 64^{\circ} 44^{\prime} 43.7^{\prime \prime W}\right)$ (Genbank codes EU559076, EU559077, EU559078, EU559079, and EU559080). Bermejo 2.2: UMSS GEN1712, 1, UMSS GEN1713, 1, UMSS GEN1714, 1, UMSS GEN1715, 1, and UMSS GEN1716, 1, río Camacho, tributary to río Tarija, Padcaya, Arce Province (2142'22.0"S 64³8’51.6"W) (Genbank codes EU559081, EU359425, EU559082, EU559083, and EU559084).

\section{Literature Cited}

Alonso, R. N., B. Bookhagen, B. Carrapa, I. Coutand, M. Haschke, G. E. Hilley, L. Schoenbohm, E. R. Sobel, M. R. Strecker, M. H. Trauth \& A. Villanueva. 2006. Tectonics, climate, and landscape evolution of the southern central Andes: The Argentine Puna Plateu and adjacent regions between 22 and $30^{\circ} \mathrm{S}$ lat. Pp. 265-283. In. The Andes. O. Oncken, G. Chong, G. Franz, P. Giese, H. J. Götze, V.A. Ramos, M. R. Strecker \& P. Wigger (Eds). Berlin, Springer. 570 p.

Armbruster, J. W. 2004. Phylogenetic relationships of the suckermouth armoured catfishes (Loricariidae) with emphasis on the Hypostominae and Ancistrinae. Zoological Journal of the Linnean Society, 141: 1-80.

Arratia, G., M. B. Peñafort \& S. Menu Marque. 1983. Peces de la región Sureste de los Andes y sus probables relaciones biogeográficas actuales. Deserta, 7: 48-107.

Arratia, G. \& S. Menu Marque. 1984. New catfishes of the genus Trichomycterus from the high Andes of South America (Pisces, Siluriformes) with remarks on distribution and ecology. Zoologische Jahrbücher. Abteilung für Systematik, Ökologie und Geographie der Tierre, 111: 493-520.

Bandelt, H.-J., P. Forster \& A. Röhl. 1999. Median-joining networks for inferring intraspecific phylogenies. Molecular Biology and Evolution, 16(1): 37-48.

Barros, S. E., G. Monasterio de Gonzo \& M. Mosquera. 2001. Ecologia trófica de peces en un río mesoeutrófico en el noroeste de Argentina. Boletin de la Sociedad de Biologia de Concepción, 72: 7-23.

Böhlke, E. B. 1984. Catalog of type specimens in the Ichthyological Collection of the Academy of Natural Sciences of Philadelphia. Special Publication 14. The Academy of Natural Sciences of Philadelphia. 245p.
Bookstein, F. L. 1989. "Size and Shape": A comment on semantics. Systematic Zoology, 38(2): 173-180.

Burgess, W. E. 1989. An atlas of freshwater and marine catfishes. A preliminary survey of the Siluriformes. T.F.H. Publications. 784p.

Covain, R. \& S. Fisch-Müller. 2007. The genera of the Neotropical armored catfish subfamily Loricariinae (Siluriformes: Loricariidae): a practical key and synopsis. Zootaxa, 1462: 1-40.

Eigenmann, C. H. 1911. Catalogue of the fresh-water fishes of tropical and south temperate America. Reports of the Princeton University Expedition to Patagonia, 1896-1899, 3(4):375-511.

Excoffier, L., G. Laval \& S. Schneider. 2005. Arlequin ver. 3.0: An integrated software package for population genetics data analysis. Evolutionary Bioinformatics Online, 1:47-50

Felsenstein, J. 1985. Confidence limits on phylogenies: an approach using the bootstrap. Evolution, 39: 783-791.

Fernández, L. A. 1996. Dos nuevas localidades para Ixinandria steinbachi (Pisces: Loricariidae). Neotrópica, 42(107-108): 22.

Ferraris, C. J., Jr. 2003. Subfamily Loricariinae. Pp. 330-350. In: R. E. Reis, S. O. Kullander \& C. J. Ferraris, Jr. (Eds). 2003. Checklist of the freshwater fishes of South and Central America. Edipucrs, Porto Alegre, 729p.

Ferraris, C. J., Jr. 2007. Checklist of catfishes, recent and fossil (Osteichthyes: Siluriformes), and catalogue of siluriform primary types. Zootaxa, 1418: 1-628.

Ghedotti, M. J. 1998. Phylogeny and classification of the Anablepidae (Teleostei: Cyprinodontiformes). Pp. 561-582. In: L. R. Malabarba, R. E. Reis, R. P. Vari, Z. M. S. Lucena \& C. A. S. Lucena (Eds.). Phylogeny and classification of Neotropical fishes. Edipucrs, Porto Alegre, 603p.

Gomes, L. A. 1947. A small collection of fishes from Río Grande do Sul, Brazil. Miscellaneous Publications of the Museum of Zoology, University of Michigan, 67: 1-39.

Gosline, W. A. 1945. Catálogo dos nematognatos de águadoce da América do Sul e Central. Boletim do Museu Nacional, série Zoologia, 33: 1-138.

Gosline, W. A. 1947. Contributions to the classifications of the loricariid catfishes. Arquivos do Museu Nacional, 41: 79-134.

Hall, T. A. 1999. BioEdit: a user-friendly biological sequence alignment editor and analysis program for Windows 95/ 98/NT. Nucleic Acids Symposium Series, 41: 95-98.

Hebert, P. D. N., A. Cywinska, S. L. Ball \& J. R. Waard. 2003. Biological identifications through DNA barcodes. Proceedings of the Royal Society of London, B, 270: 313-321.

Iriondo, M. 1993. Geomorphology and Late Quaternary of the Chaco (South America). Geomorphology, 7: 289-303.

Isbrücker, I. J. H. 1973. Redescription and figures of the South American mailed catfish Rineloricaria lanceolata (Günther, 1868) (Pisces, Siluriformes, Loricariidae). Beaufortia. 278 (21): 75-89.

Isbrücker, I. J. H. 1979. Descriptions préliminaires de nouveaux taxa de la famille des Loricariidae. Revue Française d'Aquariologie, 5: 86-116.

Isbrücker, I. J. H. 1980. Classification and catalogue of the mailed Loricariidae (Pisces, Siluriformes). Verslagen en Technische Gegevens. Instituut voor Taxonomische 
Zoölogie (Zoölogisch Museum) Universiteit van Amsterdam, 22: 1-181.

Isbrücker, I. J. H. 1981a. A treatise of the Loricariidae Bonaparte, 1831, a family of South American mailed catfishes, with emphasis on the subfamily Loricariinae (Pisces, Siluriformes). Unpublished Ph.D. dissertation, Universiteit van Amsterdam.

Isbrücker, I. J. H. 1981b. Revision of Loricaria Linnaeus, 1758 (Pisces, Siluriformes, Loricariidae). Beaufortia, 31: 51-96.

Isbrücker, I. J. H. 2001. Nomenklator der Gattungen und Arten der Harnischwelse, Familie Loricariidae Rafinesque, 1815 (Teleostei: Ostariophysi). DATZ- Sonderheft, Harnischwelse 2: 25-32.

Isbrücker, I. J. H. \& H. Nijssen. 1978. Two new species and a new genus of neotropical mailed catfishes of the subfamily Loricariinae Swainson, 1838 (Pisces, Siluriformes, Loricariidae). Beaufortia, 27: 177-206.

Kumar, S., K. Tamura \& M. Nei. 2004. MEGA3: integrated software for molecular evolutionary genetics analysis and sequence alignment. Briefings in Bioinformatics, 5: 150-163.

Liotta, J. 2006. Distribución geográfica de los peces de aguas continentals de la República Argentina. ProBiota (FCNyM, UNLP) Serie Documentos no 3: 701p.

López, H., R. Menni \& A. Miquelarena. 1987. Lista de los peces de agua dulce de la Argentina. Biología Acuática, 12: 1-50.

López, H. L., C. C. Morgan \& M. J. Montenegro. 2002. Ichthyological ecoregions of Argentina. ProBiota (Electronic Version): 1-68.

López, H. L., A. M. Miquelarena \& R. C. Menni. 2003. Lista comentada de los peces continentales de Argentina. ProBiota (FCNyM, UNLP) Serie Técnica y Didáctica n 5: 1-85.

López, H. L. \& A. M. Miquelarena. 2005. Biogeografia de los peces continentales de la Argentina. Pp. 509-550. In: J. Llorente Bousquets \& J. J. Morrone (Eds.). Regionalización biogeográfica en Latinoamérica y tópicos afines. Primeras Jornadas Biogeográficas de la Red Iberoamericana de Biogeografía y Entomología Sistemática.

Menni, R. C. 2004. Peces y ambientes en la Argentina continental. Monografias del Museo Argentino de Ciencias Naturales, 5: 1-314.

Menni, R. C., A. M. Miquelarena \& A.V. Volpedo. 2005. Fishes and environment in northwestern Argentina: from lowland to Puna. Hydrobiologia, 544: 33-49.

Monasterio de Gonzo, G. 2002. Estudio morfológico de la dentición de tres especies de loricáridos del Noroeste Argentino (Teleostei, Siluriformes). Physis, 60: 11-18.

Monasterio de Gonzo, G. 2003. Peces de los Rios Bermejo, Juramento y cuencas endorreicas de la Provincia de Salta. Museo de Ciencias Naturales \& Consejo de Investigación Universidad Nacional de Salta. 243p.

Monasterio de Gonzo, G., M. C. Costa \& M. E. Mosqueira. 1994. Distribución de los peces Siluriformes en la provincial de Salta, Argentina. Tankay, 1: 250-251.

Monasterio de Gonzo, G., V. Martinez, R. Vera \& D. Santos. 1998. Utilización de recursos y estructura en gremios de comunidades de peces en rios de bajo orden. Boletin de la Sociedad de Biologia de Concepción, 69: 131-140.
Monasterio de Gonzo, G., S. E. Barros \& M. Mosqueira. 2005. Estructura en gremios y composición de la ictiofauna del Parque Nacional El Rey, provincia de Salta, Argentina. Natura Neotropicalis, 36: 35-43.

Monasterio de Gonzo, G., S. E. Barros, O. Mamani \& M. Mosqueira. 2005. Ictiofauna del área noroeste de la cuenca Párano-Platense. Natura Neotropicalis, 36: 21-33.

Nieva, L. B., R. V. Mesones \& S. E. Ferreira. 2001. Variación estacional en la composición de especies de peces en el paraje La Ciénaga, río Arias, Salta, Argentina. Boletin de la Sociedad de Biologia de Concepción, 72: 83-89.

Posada, D. \& K. A. Crandall. 1998. Modeltest: testing the model of DNA substitution. Bioinformatics, 14: 817-818.

Pozzi, A. J. 1945. Sistemática y distribución de los peces de agua dulce de la República Argentina. Gaea, 7: 239-292.

Reis, R. E. \& A. R. Cardoso. 2001. Two new species of Rineloricaria from southern Santa Catarina and northeastern Rio Grande do Sul, Brazil (Teleostei: Loricariidae). Ichthyological Exploration of Freshwaters, 12: 319-332.

Reis, R. E \& E. H. L. Pereira. 2000. Three new species of the loricariid catfish genus Loricariichthys (Teleostei: Siluriformes) from southern South Amerrica. Copeia, 2000(4): 1029-1047.

Reis, R. E., S. O. Kullander \& C. J. Ferraris, Jr. (Eds). 2003. Checklist of the freshwater fishes of South and Central America. Edipucrs, Porto Alegre, 729p.

Ringuelet, R. A \& R. H. Arámburu. 1962. Peces Argentinos de agua dulce. Claves de reconocimiento y caracterización de familias y subfamilias, con glosario explicativo. Agro, 3: 1-98.

Ringuelet, R. A., R. H. Arámburu \& A. Alonso de Arámburu. 1967. Los peces Argentinos de agua dulce. Comisión de Investigaciones Cientificas de la Provincia de Buenos Aires, La Plata. 602p.

Sambrook, J., E. F. Fritsch \& T. Maniatis. 1989. Molecular cloning: A laboratory manual. 2 Ed. Cold Spring Harbor Press, Cold Spring Harbor, New York.

Schaefer, S. A. 1997. The Neotropical cascudinhos: Systematics and biogeography of the Otocinclus catfishes (Siluriformes: Loricariidae). Proceedings of the Academy of Natural Sciences of Philadelphia, 148: 1-120.

Swoford, D. L. 2001. PAUP*. Phylogenetic Analysis Using Parsimony (*and Other Methods). Version 4. Sinauer Associates, Sunderland, Massachusetts.

Taylor, W. R. \& G. C. Van Dyke. 1985. Revised procedures for staining and clearing small fishes and other vertebrates for bone and cartilage study. Cybium, 9: 107-119.

Thompson, J. D., T. J. Gibson, F. Plewniak, F. Jeanmoughin \& D. G. Higgins. 1997. The CLUSTAL X windows interface: flexible strategies for multiple sequence alignment aided by quality analysis tools. Nucleic Acids Research, 25: 4876-4882.

Ward, R. D., T. S. Zemlak, B. H. Innes \& P. R. Last. 2005. DNA barcoding Australia's fish species. Philosophical Transactions of the Royal Society, 360: 1847-1857.

Accepted August, 2008

Published September 30, 2008 